\title{
Komunikasi Antar Budaya Warga Desa Padang Jering Kecamatan Batang Asai, Kabupaten Sarolangun, Jambi
}

\author{
Zulpikal, Zulqarnin, Arfan, Dian Mursyidah, Neneng Hasanah \\ UIN Sulthan Thaha Saifuddin Jambi \\ Email: arfan@uinjambi.ac.id
}

\begin{abstract}
Abstrak: Penelitian ini dilatarbelakangi oleh kehadiran pendatang di Desa Padang Jering, Sarolangun yang menuntut mereka melakukan komunikasi dengan penduduk lokal. Artikel ini akan mendeskripsikan latar belakang sosial budaya yang memengaruhi praktek komunikasi penduduk, dan hambatan komunikasi antarbudaya penduduk lokal dan penduduk pendatang di Desa Padang Jering, serta mengetahui solusi terhadap hambatan komunikasi tersebut. Menggunakan metode penelitian kualitatif dengan jenis penelitian lapangan (field reseaech), penelitian melakukan observasi dan wawancara para informan pada pertengahan tahun 2020. Penelitian ini menemukan bahwa unsur-unsur budaya yang memengaruhi seperti bahasa, sistem religi dan pengetahuan. Hambatan dalam komunikasi antarbudaya penduduk lokal dan penduduk pendatang yaitu hambatan semantik dan bahasa. Upaya dalam menghindari hambatan komunikasi antarbudaya penduduk lokal dan pendatang di Desa Padang Jering yang pertama, menggunakan bahasa isyarat seperti senyum untuk tetap bisa berkomunikasi. Kedua, dengan menggunakan bantuan orang lain menjadi perantara untuk berkomunikasi dengan penduduk lokal, termasuk mengajarkan bahasa lokal. Ketiga, dengan menggunakan bahasa Indonesia ketika ingin berkomunikasi. Peneliti merekomendasikan sikap saling memahami dalam kebudayaan mapun hal-hal lain yang memiliki perbedaan, dan toleransi supaya bisa berkomunikasi dengan lancar dan dapat menghindari hambatan komunikasi antarbudaya.
\end{abstract}

Kata-kata kunci: komunikasi antarbudaya, lokal-pendatang, Padang Jering.

\section{A. Pendahuluan}

Komunikasi adalah hubungan kontak antar manusia, baik individu maupun kelompok dalam kehidupan sehari-hari. ${ }^{1}$ Komunikasi adalah bagian dari kehidupan manusia itu sendiri. Sejak dilahirkan sudah berkomunikasi dengan lingkungannya, sementara itu manusia mempunyai karakteristik yang berbeda-beda yang terbentuk dari

${ }^{1}$ Onong Uchjana Effendy, Ilmu Komunikasi; Teori dan Praktek, (Bandung: Remaja Rosdakarya, 2000), 8. 
faktor lingkungan dan kebudayaan yang ada di daerahnya, sehingga adanya toleransi keberagaman dan saling keterbukaan antar budaya pun sangat dibutuhkan untuk saling hidup berdampingan sebagai makhluk sosial.

Bahkan perbedaan inilah yang mendasari kita untuk saling mengenal satu sama lain sebagai salah satu ciptaan Allah SWT, Allah berfirman dalam Alqur'an surah Al Hujarat ayat 13 yang berbunyi ${ }^{2}$ :

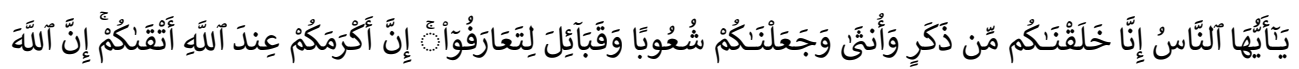
عَلِيمٌ خَبِيرٌ

"Hai manusia, sesungguhnya Kami menciptakan kamu dari seorang laki-laki dan seorang perempuan dan menjadikan kamu berbangsa-bangsa dan bersuku-suku supaya kamu saling kenal-mengenal. Sesungguhnya orang yang paling mulia di antara kamu disisi Allah ialah orang yang paling takwa diantara kamu. Sesungguhnya Allah Maha Mengetahui lagi Maha Mengenal (QS.Al-Hujarat:13)"

Firman Allah di atas memberikan pemahamanbahwa kita sebagai manusia harus saling menjaga silaturahmi antar satu dengan yang lain dan hendaklah kita saling mengenal satu sama lain, saling melengkapi, saling menghargai perbedaan dengan yang lainnya.Kemudian konteks surah al-hujarat dapat kita lihat dari fenomena keberagaman budaya yang ada di Indonesia pemahaman akan kebudayaan dan berinteraksi dan beradaptasi harus selalu disesuaikan agar tidak terjadi konflik antar individu atau kelompok dalam keberagaman budaya. Beradaptasi menjadi salah satu solusi untuk memahami budaya yang ada di Indonesia.

Budaya didefinisikan sebagai tatanan pengetahuan pengalaman, kepercayaan nilai, sikap, makna dan diwariskan dari generasi ke generasi melalui usaha individu dan kelompok. $^{3}$ Proses pemahaman budaya dapat dilakukan dengan berbagai cara seperti Salah satunya yaitu dengan komunikasi antar budaya, dengan melalui komunikasi antar budaya maka seseorang maupun individu dan kelompok akan bisa memahami kebudayaan orang lain baik itu kebudayaan yang dari lokal maupun kebudayaan dari luar daerah tempat tinggalnya.oleh karena itu melalui pengaruh budaya lah orang-orang belajar berkomunikasi.

${ }^{2}$ QS.Al-Qur'an Surat Al-Hujarat ayat 13.

${ }^{3}$ Sihabudin Ahmad, Komunikasi AntarBudaya Satu Persfektif Multidimensi, (Jakarta: PT Bumi Aksara,2011),15. 
Padang Jering merupakan sebuah desa yang terletak dalam (daerah) kecamatan Batang Asai, Kabupaten Sarolangun, Provinsi Jambi, Indonesia. Desa Padang Jering juga memiliki beragam budaya asli atau kebudayaan lokal dari daerah tersebut, seperti budaya pernikahan, turun mandi dan termasuk juga bahasa, logat dan cara berkomunikasi yang khusus dari desa tersebut dalam berinteraksi dengan masyarakat setempat.

Dalam berkomunikasi dengan orang lain atau dengan penduduk pendatang yang bukan asli, masyarakat Desa Padang Jering mempunyai gaya bahasa atau cara berkomunikasi antar budaya supaya terciptanya hubungan sosial harmoni antara peduduk lokal dengan penduduk pendatang dalam proses komunikasi. Bahasa yang digunakan oleh masyarakat desa Padang Jering sebenarnya sama dalam pengucapannya namun ada yang membedakan yaitu sesuai logat dan iramanya, bahasa yang digunakan adalah bahasa Melayu tinggi yaitu bahasa yang sedikit bercampur antara bahasa Palembang dan Padang.

Berdasarkan observasi awal, cara komunikasi yang digunakan Penduduk Lokal Desa Padang Jering adalah dengan menggunakan bahasa daerah Desa Padang Jering, dan logat penduduk lokal Desa Padang Jering memiliki logat yang khusus, kemudian dalam mengucapkan kata-kata bernada keras dan terdengar kasar. Berbeda dengan penduduk pendatang yang bukan asli Desa Padang Jering seperti Jawa, Minang maupun daerah lain dalam berkomunikasi tentunya memiliki gaya bahasa yang berbeda pula, dan Penduduk Pendatang pun juga memiliki kebudayaan bahkan memiliki gaya bahasa yang berbeda pula dalam proses komunikasi. Dalam proses komunikasi antara Penduduk lokal Desa Padang Jering dengan Penduduk Pendatang tentunya akan mendatangkan hambatan-hambatan dalam berkomunikasi yang diakibatkan perbedaan kebudayaan terutama dalam gaya bahasa dan berkomunikasi. Untuk menghindari hambatan dalam komunikasi tersebut maka diperlukanlah proses pemahaman atau saling memahami kebudayaan masing-masing baik penduduk lokal Desa Padang Jering maupun penduduk pendatang terutama dalam berkomunikasi supaya terciptanya interkasi sosial karena manusia adalah mahluk sosial.

Berdasarkan uraian di atas, maka tujuan penelitian mengetahui perbedaan latar belakang sosial budaya penduduk lokal dan penduduk pendatang di Desa Padang Jering, memahami hambatan komunikasi antarbudaya penduduk lokal dan penduduk 
pendatang di Desa Padang Jering dan mengetahui upaya menghindari hambatan komunikasi antarbudaya penduduk lokal dengan penduduk pendatang di Desa Padang Jering. Metode yang digunakan untuk sampai kepada tujuan penelitian adalah menggunakan metode kualitatif dengan observasi dan wawancara para informan. Salah seorang peneliti yang merupakan bagian dari warga Padang Jering menjadi bagian yang memudahkan penyediaan data.

\section{B. Implementasi Komunikasi antar Budaya}

Pada umumnya komunikasi dapat mempunyai beberapa tujuan antara lain: ${ }^{4}$ pertama, supaya pesan yang disampaikan dapat dimengerti sehingga komunikan dapat mengikuti apa yang kita maksudkan; kedua, memahami orang lain, dan agar gagasan kita dapat diterima oleh orang lain dengan pendekatan yang persuasif tanpa memaksakan kehendak; ketiga, menggerakkan orang lain untuk melakukan sesuatu dengan cara mendorong secara baik untuk melakukan.

Budaya atau kebudayaan berasal dari bahasa sansekerta yaitu buddhayah, yang merupakan bentuk jamak dari buddhi (budi atau akal) diartikan sebagai hal- hal yang berkaitan dengan budi dan akal manusia. Bahasa Inggris menyebut kebudayaan sebagai culture, yang berasal dari kata latin colere yaitu mengolah atau mengerjakan, dapat diartikan juga sebagai mengolah tanah atau Bertani. Kata culture juga kadang sering diterjemahkan sebagai "kultur" dalam bahasa Indonesia. ${ }^{5}$

Hal yang sama juga diungkapkan oleh Koentjaraningrat bahwa 'kebudayaan' berasal dari kata sansekerta buddhayah bentuk jamak dari buddhi yang berarti budi atau akal, sehingga menurutnya kebudayaan dapat diartikan sebagai hal- hal yang bersangkutan dengan budi dan akal, ada juga yang berpendapat sebagai suatu perkembangan dari majemuk budi-daya yang artinya daya dari budi atau kekuatan dari akal. ${ }^{6}$ Kuntjaraningrat berpendapat bahwa kebudayaan mempunyai paling sedikit tiga wujud, yaitu pertama sebagai suatu ide, gaagsan, nilai- nilai norma-norma peraturan dan

\footnotetext{
2008). 25

${ }^{4}$ Dani Fardiansyah, Filsafat Ilmu Komunikasi Suatu Pengantar, Cet II (Jakarta: Indeks, ${ }^{5}$ Sihabudin Ahmad, Komunikasi AntarBudaya Satu Persfektif Multidimensi, (Jakarta: PT Bumi Aksara,2011),15.

${ }^{6}$ Koentjaraningrat, Kebudayaan, Mentalitas dan Pembangunan, (Jakarta: Gramedia Pustaka Utama, 1993), 9.
} 
sebagainya, kedua sebagai suatu aktifitas kelakuan berpola dari manusia dalam sebuah komunitas masyarakat, ketiga benda benda hasil karya manusia.

Seorang ahli bernama Ralph Linton yang memberikan definisi kebudayaan yang berbeda dengan perngertian kebudayaan dalam kehidupan sehari- hari. Menurutnya, kebudayaan adalah seluruh cara kehidupan dari masyarakat dan tidak hanya mengenai sebagian tata cara hidup saja yang dianggap lebih tinggi dan lebih diinginkan. Jadi kebudayaan menunjuk pada berbagai aspek kehidupan, istilah ini meliputi cara- cara berlaku, kepercayaan-kepercayaan dan sikap-sikap dan juga hasil dari kegiatan manusia yang khas untuk suatu masyarakat atau kelompok penduduk tertentu. Sementara Selo Soemardjan dan Soeleman Soemardi merumuskan kebudayaan sebagai semua hasil karya, rasa dan cipta masyarakat. Karya masyarakat menghasilkan teknologi dan kebudayaan kebendaan atau kebudayaan jasmaniah yang diperlukan oleh manusia untuk menguasai alam sekitarnya agar kekuatan serta hasilnya dapat diabadikan untuk keperluan masyarakat. ${ }^{7}$

Tylor mendefinisikan kultur sebagai suatu keseluruhan yang kompleks termasuk didalamnya pengetahuan, kepercayaan, kesenian moral, hukum adat dan segala kemampuan dan kebiasaan lain yang diperoleh manusia sebagai seorang anggota masyarakat. ${ }^{8}$ Kroeber dan kluckhohn merumuskan definisi kultur dengan pola- pola tingkah laku dan pola- pola untuk bertingkah laku, baik yang eksplisit maupun yang implisit yang diperoleh dan diperoleh melalui simbol simbol yang membentuk pencapaian yang khas dari kelompok-kelompok manusia, termasuk perwujudannya dalam benda- benda materi. ${ }^{9}$ Linton menerjemahkan budaya sebagai keseluruhan dari pengetahuan, sikap dan pola perilaku yang memrupakan kebiasaan yang dimiliki dan diwariskan oleh anggota suatu masyarakat tertentu. ${ }^{10}$

Salah satu tokoh yang memberikan pandangan tentang kebudayan serta telah jauh memberikan landasan berfikir tentang arti budaya adalah Clifford Geertz. Menurutnya kebudayaan adalah suatu sistem makna dan symbol yang disusun dalam pengertian dimana individu- individu mendefinisikan dunianya, menyatakan

${ }^{7}$ Jacobus Ranjabar, Sistem Sosial Budaya Indonesia; Suatu Pengantar (Bogor: GHalia Indonesia, 2006), 21.

${ }^{8}$ William A. Haviland, Antropologi, Jilid 1 (Jakarta: Erlangga, 1985), 332.

${ }^{9}$ William A. Haviland, Antropologi, 333.

${ }^{10}$ Roger M. Keesing, Antropologi Budaya, Suatu Prespektif Kontemporer, Jilid 1, (Jakarta: Erlangga, 1989), 68. 
perasaannya dan memberikan penilaian- penilaiannya, suatu pola makna yang ditransmisikan secara historis, diwujudkan dalam bentuk- bentuk simbolik melalui sarana dimana orang- orang mengkomunikasikan, mengabdikan, dan mengembangkan pengetahuan, karena kebudayaan merupakan suatu sistem simbolik maka haruslah dibaca, diterjemahkan dan diinterpretasikan. ${ }^{11}$

Sistem. komunikasi verbal dan nonverbal membedakan suatu kelompok dari kelompok lainnya adalah bagian penting dari kebudayaan. Terdapat banyak "bahasa asing "di dunia sejumlah bangsa memiliki Lima belas atau lebih bahasa utama (dalam suatu kelompok bahasa terdapat dialek, Logajargon dan ragam lainnya) lebih jauh lagi. Makna-makna yang diberikan kepada gerak-gerik misalnya sering berada secara kultural.

Komunikasi antarbudaya terjadi bila produsen pesan adalah anggota anggota suatu budaya dan penerima pesan nya adalah anggota suatu budaya lain. Dalam keadaan demikian, kita segera dihadapkan kepada masala masalah yang ada dalam suatu situasi di mana suatu pesan disandi dalam suatu budaya dan haus disandi balik dalam budaya lain. Seperti telah kita lihat, budaya mempengaruhi orang yang berkomunikasi. Budaya bertangung jawab atas seluruh perbendaharaan perilaku komunikatif dan makna yang dimiliki setiap orang. Konsekuensinya, perbendaharaanperbendaharaan yang dimiliki dua orang yang berbeda budaya akan berbeda pula, yang dapat menimbulkan segala macam kesulitan. ${ }^{12}$

Hamid Mowland juga berpendapat bahwa komunikasi antar budaya sebagai human flow across national boundaries. Asumsi tersebut merupakan sekelompok manusia yang menyebrangi lintas budaya. Seperti adanya keterlibatan suatu konferensi internasional di mana bangsa-bangsa dari berbagai negara berkumpul dan berkomunikasi satu sama lain.

Dengan kata lain, komunikasi antarbudaya ini akan terjadi ketika adanya komunikasi antara orang-orang yang memiliki kebudayaan yang berbeda-beda demi mencapainya suatu tujuan komunikasi yang sama serta terjalin interaksi yang lancar pada hakekatnya.

\footnotetext{
${ }^{11}$ Roger M. Keesing, Antropologi Budaya, Suatu Prespektif Kontemporer, 70.

${ }^{12}$ Tito Edy Priandono, Komunikasi Keberagaman, (Bandung: Remaja Rosdakarya, 2016), 32.
} 
Sedangkan menurut para ahli yang lain ada yang berpendapat seperti Sitaram yang mengatakan bahwa komunikasi antarbudaya merupakan seni untuk memahami dan saling pengertian antara khalayak yang berbeda kebudayaan. Berbeda halnya dengan Srnover dan Porter yang berpendapat bahwa komunikasi antarbudaya terjadi manakala bagian yang terlibat dalam kegiatan komunikasi tersebut mempunyai latar belakang budaya dan pengalaman yang berbeda. Latar belakang tersebut mencerminkan nilai yang dianut oleh kelompoknya berupa pengalaman, pengetahuan, dan nilai.

Kemudian, Rich menyimpulkan bahwa komunikasi antarbudaya terjadi ketika orang-orang yang berbeda kebudayaan dipertemukan. Sehingga, dapat ditarik kesimpulan, bahwa komunikasi antar budaya ini merupakan komunikasi yang terjadi ketika kedua orang atau lebih sedang proses berkomunikasi, untuk mencapai pemahaman, maupun pengertian yang terjadi di antara khalayak yang berbeda kebudayaan. Oleh karena itu, kegiatan inilah yang membawa keselarasan dalam berkomunikasi. ${ }^{13}$

Fungsi komunikasi antarbudaya terbagi menjadi dua bagian yaitu fungsi pribadi dan fungsi sosial. ${ }^{14}$ Fungsi pribadi adalah fungsi komunikasi yang ditunjukkan melalui perilaku komunikasi yang bersumber dari seorang individu, untuk enyatakan Identitas Sosial, Menyatakan Integrasi Sosial, Menambah Pengetahuan, dan untuk melepaskan diri atau mencari jalan keluar atas masalah-masalah yang sedang kita hadapi. Sementara fungsi sosial komunikasi, yaitu: pengawasan, menjembatani, sosialisasi nilai, dan menghibur.

Prinsip-Prinsip Komunikasi Antarbudaya dapat dibagi menjadi 6 bagian yaitu: ${ }^{15}$ Relativitas Bahasa yang disuarakan oleh para antropologis linguistic, Bahasa Sebagai Cermin Budaya, Mengurangi Ketidak-pastian, Kesadaran Diri dan Perbedaan, Interaksi Awal dan Perbedaan, serta Memaksimalkan Hasil Interaksi.

Dalam komunikasi antarbudaya seperti dalam semua komunikasi kita berusaha memaksimalkan hasil interaksi. Namun seringkali yang dijumpai adalah hambatan.

${ }^{13}$ Deddy Mulyana, Rahmat Jalaluddin, Komunikasi Antar Budaya Panduan Berkomunikasi Dengan Orang-orangBerbedaBudaya, (Jakarta: Remaja Rosdakarya, 2005), 20.

${ }^{14}$ AhmadSihabudin, Komunikasi Antar Budaya, (Jakarta: Bumi Aksara, 2011), 105.

${ }^{15}$ Ahmad Sihabudin, Komunikasi AntarBudaya, 110. 
Adapun hambatan-hambatan komunikasi antarbudaya dibedakan menjadi tiga macam yaitu: ${ }^{16}$

a. Hambatan yang bersifat teknis, antara lain seperti:

1) Kurangnya sarana dan prasarana yang diperlukan dalam proses komunikasi.

2) Penguasaan teknik dan metode berkomunikasi yang tidak sesuai.

3) Kondisi fisik yang tidak memungkinkan terjadinya proses komunikasi.

4) Komunikan yang tidak siap menerima pesan dari komunikator

b. Hambatan semantik.

Semantik dapat diartikan sebagai suatu studi tentang pengertian. Dimana pengertian dapat diungkapkan melalui bahasa, baik bahasa lisan (melalui ucapan) bahasa tubuh, maupun bahasa tertulis. Meskipun bahasa merupakan alat komunikasi yang paling efektif, tetapi bahasa dapat juga menjadi hambatan dalam proses komunikasi apabila bahasa yang dipergunakan dalam berkomunikasi tidak dimengerti oleh orang lain sebagai penerima pesan komunikasi.

Jadi yang dimaksud dengan hambatan semantik ialah hambatan yang disebabkan oleh kesalahan dalam penafsiran, kesalahan dalam memberikan pengertian terhadap bahasa (kata-kata, kalimat, kode) yang dipergunakan dalam proses komunikasi. Kesalahan dalam menangkap pengertian terhadap bahasa biasanya dapat terjadi karena perbedaan latar belakang budaya.

c. Hambatan perilaku.

Hambatan perilaku disebut juga dengan hambatan kemanusiaan, adalah hambatan yang disebabkan oleh berbagai bentuk sikap dan perilaku, baik dari komunikator maupun dari komunikan. Adapun hambatan perilaku dapat tampak dalam berbagai bentuk, diantaranya: Pandangan yang bersifat apriori (negatif), Prasangka yang didasarkan pada emosi, dan Otoritas dan sifat-sifat negatif lainnya.

\section{Budaya Penduduk Lokal-Pendatang di Desa Padang Jering}

Sejarah Desa Padang Jering Pada tahun 1940 Zaman Demang saat itu dipimpin oleh Demang Makalam berasal dari Tangkui Sekaladi bapaknya Abunjani yang memimpin Margo Tengah, dari keturunan beliau ditambah lagi pendatang dari Padang dan Kerinci berkembanglah anak cucu beliau, seiring wangktu masuklah pada zaman

${ }^{16}$ Ahmad Sihabudin, Komunikasi AntarBudaya, (Jakarta: Bumi Aksara, 2011), 106. 
penjajahan Belanda disebut dengan Zaman Pasirah, saat itu dipimpin oleh Raja H. Sari, Pasirahnya H. Yunus pada saat itu dibentuklah Rio / kelompok- kelompok, menjadi 2 yaitu Padang Jering Ulu dan Padang Jering Batin, Datuk Maha Raja Besar terletak di Ulu sedangkan Rio terletak dibatin, yang dinamakan "adat lamo pasko usang diasak layu, dianggung mati" Adat pun dibagi menjadi dua Padang Jering Ulu disebut Penghulu yang artinya kaya "Setae Sapao" sedangkan Padang Jering Batin disebut Adebalang yang artinya keras, jaguk "Belah Nan Tujuh" Rio Padang Jering Ulu dipimpin oleh Muis sedangkan Padang Jering Batin dipimpin oleh Jubang kemudian orde berikutnya Padang Jering Ulu dipimpin oleh Abdullah sedangkan Padang Jering Batin dipimpin oleh Darun, saat itu juga Rio berubah menjadi Kepala Dusun pada Orde berikutnya Padang Jering Ulu dipimpin oleh Sulaiman dan Padang Jering Batin dipimpin oleh Nordin kemudian dilanjut lagi dengan Padang Jering Batin dipimpin oleh H. Bawi dan Padang Jering Batin dipimpin oleh $\mathrm{H}$. Ibrahim, pada saat kepemimpinan beliau ini terjadilah keributan penguasaan wilayah, nah dari sini digabunglah dua dusun ini menjadi satu menjadi "DESA" dinamakanlah Desa PADANG JERING. ${ }^{17}$

Bahasa juga alat yang digunakan untuk dapat berkomunikasi sehari-hari, baik bahasa lisan ataupun bahasa tulisan. sebagai negara Indonesia tentunya bahasa persatuan adalah bahasa Indonesia, tetapi karena Idonesia memiliki banyak keberagaman kebudayaan dan salah satunya adalah bahasa. Begitu pula dengan bahasa yang di gunakan oleh penduduk suatu daerah. Tentu daerah tersebut mempunyai ciri khas bahasa daerah tersendiri.

Bahasa daerah Batang Asai adalah bahasa yang merupakan campuran dari bahasa Padang dan Melayu, sedangkan logat dan gaya bahasanya bernada keras dan agak kasar. Walaupun sebagian dari penduduk Lokal Desa Padang Jering bisa berbahasa Indonesia tetapi masih ada sebagian penduduk lokal yang tidak bisa berbahasa Indonesia. Terkadang walaupun penduduk lokal menggunakan bahasa Indonesia tetapi tetap saja menggunkan logat daerah Batang Asai. Saat berkomunikasi penduduk lokal tidak memiliki bahasa dan gaya bahasa tersendiri ketika berkomunikasi dengan orang lain. Tidak terlalu ada batasan bahasa atau bentuk komunikasi.

Sesuai hasil wawancara penulis dengan Idris Kepala Adat Desa Padang Jering mengatakan,

\footnotetext{
${ }^{17}$ Dokumentasi Desa Padang Jering 2019.
} 
"Bahasa daerah Padang Jering berbeda dengan bahasa daerah lain, mulai dari logat dan nada bicara karena bahasa daerah Padang Jering ini berasal dari bahasa campuran antara bahasa melayu dengan bahasa Padang. Sedangkan logatnya juga meliki logat tersendiri, bahkan nada bicaranya kerasa dan terdengar agak kasar. Tidak semua penduduk Padang Jering yang bisa berbahasa Indonesia, karena masih ada sebagian penduduk Desa Padang Jering yang masih kental dengan bahasa Desa Padang Jering". ${ }^{18}$

Berbeda dengan bahasa penduduk pendatang yang memiliki bahasa yang pasti sangat berbeda dengan penduduk lokal Desa Padang Jering. bahasa Jawa adalah bahasa khas dari penduduk pendatang yang berasal dari daerah Jawa. Bahasa Jawa bahkan penduduk yang berasal dari daerah Jawa memiliki gaya bahasa yang lemah lembut. Bahasa Jawa juga memiliki tingkatan tersendiri pada saat berkomunikasi yang mana tujuan tingkatan dalam bahasa tersebut digunakan untuk membedakan cara seseorang dalam berkomunikasi, seperti bahasa komunikasi untuk yang lebih muda, seumran dan gaya bahasa untuk yang lebih tua.

Sesuai dengan hasil wawancara penulis dengan Rin penduduk pendatang mengatakan

"[K]ami orang Jawa terkenal dengan bahasanya yang lemah, lembut sopan dan santu. Bahkan logat dan nada bicaranya pun lembut. Dan ketika akan berkomunikasi maka akan menggunakan bahasa yang berbeda pula tergantung pada lawan bicara kita sendiri, dan bahasa yang digunakan harus sesuai" ${ }^{19}$

Berdasarkan hasil wawancara tersebut dapat penulis simpulkan bahwa bahasa yang digunakan penduduk lokal dan pendatang begitu sangat berbeda, mulai dari cara pengucapan, logat, dan nada bicara.

1. Pengetahuan

IImu pengetahuan begitu sangat berguna untuk kehidupan manusia, karena dengan ilmu pengetahuan maka akan bisa memperlancar segala urusan. Seperti urusan ekonomi, agama, dan lain-lain. Penduduk lokal dan pendatang di Desa Padang Jering dalam hal pengetahuan memiliki karena ilmu pengetahuan yang sama dengan penduduk pendatang di Desa Padang Jering. Seperti hal dalam bercocok tanam, berbisnis dan halhal lain mengenai ilmu pengetahuan.

${ }^{18}$ Muktar, Kepala Adat Desa Padang Jaring, Wawancara Dengan Penulis, 11 Februari 2020, Desa Padang Jering, Wawancara.

${ }_{19}$ Indra, Penduduk Pendatang, Wawancara dengan Penulis, 11 Februari 2020, Desa Padang Jering, Wawancara. 
Sesuai dengan hasil wawancara Heri penduduk lokal Desa Padang Jering mengatakan:

"[K]ami sebagai penduduk lokal Desa Padang Jering mengakui bahwa dalam bidang ilmu pengetahuan masih sama dari penduduk pendatang, dan kami banyak juga yang diajarkan oleh penduduk pendatang mulai dari cara bercocok tanam, berbisnis, dan berbudidaya. Mungkin hal ini terjadi karena latar belakang pendidikan penduduk lokal di Desa ini yang rata-rata hanya tamatan sekolah dasar dan di Desa ini juga terbatas informasi. Mungkin ini yang membuat kami saling berbagi ilmu pada bidang pengetahuan dari penduduk pendatang" 20

Dari hasil wawancara dapat penulis simpulkan bahwa dari latar belakang pengetahuan penduduk pendatang dalam bidang pengetahuan dibandingkan dengan penduduk lokal Desa Padang Jering. Sesuai hasil pengamatan penulis dilapangan bahwa ilmu pengetahuan penduduk pendatang dibandingkan penduduk lokal memiliki pengetahuan yang sama dan saling membagi pengetahuan satu sama lain. Seprti penduduk pendatang yang mengajarkan penduduk lokal bagaimana cara bercocok tanam yang baik, kemudian mengajarkan cara berbudidaya, beternak dan mendapatkan informasi yang lebih luas.

\section{Sistem Sosial}

Dalam masyarakat suku Melayu Jambi masih tampak sisa-sisa pelapisan sosial lama, ditandai adanya golongan bangsawan, golongan menengah, dan golongan orang kecik (orang kecil). Sistem pelapisan sosial ini semakin lama semakin berubah. Orang melayu Jambi hidup dengan prinsip garis keturunan yang bilateral, menjalankan prinsip bilateral dengan menempatkan faktor keluarga batih sebagai dasar perhitungan hubungan kekeluargaan. Mereka selalu memiliki hubungan kekerabatan dari pihak ibu maupun bapak. Pilihan jodoh cenderung untuk endogamy dusun. Sistem kekerabatan tersebut disebut dengan istilah "Sanak", yaitu keturunan hingga generasi ketiga. ${ }^{21}$

Kelompok ini biasanya saling membantu dalam setiap acara keluarga seperti perkawinan, kematian dan lain-lain. Hak dan kewajiban diatur berdasarkan perbedaan usia, terutama dalam setiap upacara adat. Tapi dalam kenyataannya saat ini, tingkatan sosial terlihat berdasarkan tingkat pendidikan, harta dan jabatan. Seorang kepala desa di

${ }^{20}$ Heri, Penduduk Lokal Desa Padang Jering, Wawancara dengan Penulis, 11 Februari 2020, Desa Padang Jering, Wawancara.

${ }^{21}$ Ensiklopedi Suku Bangsa di Indonesia, hlm. 137-138. http://netralnews.com/news/rsn/read/94275/mengenal-suku-melayu-jambi)) 
kalangan orang Melayu disebut sebagai "Datuk", yang relatif dijadikan panutan oleh masyarakat. $^{22}$

Dalam masyarakat Jawa, sistem kekerabatan didasarkan pada garis keturunan bilateral (diperhitungkan dari dua belah pihak, ibu dan ayah). Dengan prinsip bilateral atau parental ini, seorang Jawa berhubungan sama luasnya dengan keluarga dari pihak ibu dan juga ayah. Kekerabatan yang relatif solid biasnya terjalin dalam keturunan satu nenek moyang hingga generasi ketiga. Namun demikian, kualitas hubungan keluarga inti (nuclear family) dan keluarga luas (extended family) berbeda-beda antara satu lingkaran keluarga dengan yang lainnya, bergantung pada kondisi masing-masing keluarga. Dibanding warga yang bermukim di perkotaan, masyarakat desa relatif lebih baik dalam menjaga nilai-nilai kekerabatan dalam keluarga. Walaupun tidak terlepas dari imbas perubahan zaman, setidaknya, tradisi kerjasama dalam keluarga besar masih terasa dalam perayaan ritual adat, seperti pernikahan, kematian, pembangunan rumah, dan lainnya. ${ }^{23}$

Masyarakat Jawa mengenal sistem lapisan masyarakat yang nyata perbedanya, yaitu keturunan raja, bangsawan dan wong cilik. Gelar kebangsawanan Jawa pada umumnya diberikan kepada masyarakat keraton dan orang-orang di luar keraton yang dianggap berjasa kepada keraton. Wong cilik adalah istilah bahasa Jawa, bahasa dari orang Jawa, Indonesia yang berarti secara literal berarti orang kecil. Istilah ini digunakan untuk menggambarkan kelas sosial dalam masyarakat tradisional Jawa yang sama dengan "rakyat jelata" dalam masyarakat feodal. Istilah seberangnya adalah priyayi, yang merupakan kelas elit aristokrat atau bangsawan. ${ }^{24}$

\section{Sistem Peralatan Hidup dan Teknologi}

Sistem peralatan hidup dan teknologi penduduk lokal dan pendatang begitu jauh berbeda karena penduduk pendatang lebih canggih dibidang peralatan hidup maupun dibidang teknologi. Sedangkan penduduk lokal belum begitu mengetahui teknologi. Hal ini karena kurangnya akses dan susahnya akses untuk daerah Desa

${ }^{22}$ Zulyani, Hidayah (April 2015). Ensiklopedi Suku Bangsa di Indonesia (edisi ke-2). Jakarta: Yayasan Pustaka Obor Indonesia. hlm. 470. ISBN 978-979-461-929-2.

${ }^{23}$ http://syariah.uin-malang.ac.id/index.php/komunitas/blog-fakultas/entry/sistemkekerabatan-di-masyarakat-jawa.

${ }^{24}$ google.com/search?q=bangsawan+dalam+suku+jawa\&oq=bangsawan+dalam+suku+ja wa\&aqs=chrome..69i57j33.9400j0j7 \&sourceid=chrome\&ie=UTF-8 
Padang Jering. Peralatannya juga berbeda untuk setiap daerah sesuai dengan letak dan kondisi daerah tersebut.

Sesuai dengan hasil wawancara penulis dengan wawan penduduk lokal Desa Padang Jering:

"[J]ika dibahas mengenai peralatan hidup otomatis kami penduduk lokal maupun penduduk pendatang tidak jauh berbeda, karena semua peralatan hidup pasti sama seperti parang, dan peralatan yang lain. Tetapi jika mengenai tekonologi mungkin kami penduduk lokal memang sedikit tertinggal dari penduduk pendatang karena disebabkan oleh beberapa faktor. Tetapi sekarang karena sudah zaman teknologi peralatan dan teknologi yang dipakai sudah hamper sama". ${ }^{25}$

Masing-masing suku memiliki artefak peninggalan nenek moyangnya masing masing. Termasuk diantaranya senjata tradisional. Rata-rata senjata tradisional asli Jambi ini digunakan untuk berburu, bertarung, upacara keagamaan, kelengkapan upacara pernikahan, upacara penganten sunat, penyambutan tamu. Diantaranya Badik Tumbuk Lada, Keris Siginjai, senjata sumpit, Pedang selangkeh, dan Tombak Jambi. ${ }^{26}$

Suku Jawa dikenal juga dengan senjata tradisional yang memiliki berbagai makna dan bentuk yang unik. Salah satu senjata khas Jawa yaitu keris. Keris merupakan alat pusaka yang sangat penting yang juga dipercaya memiliki kesaktian. Keris dibuat oleh para Mpu yang ditempa serta diberi mantra-mantra. Salah satu keris yang melegenda ialah keris Mpu Gandring dalam cerita Ken Arok karena mampu menjadikannya sebagai penguasa kerajaan Singasari. ${ }^{27}$

Sesuai dengan perkembangan zaman peralatan hidup yang digunakan oleh penduduk lokal dan pendatang sudah mengikuti perkembangan zaman, seperti sudah menggunakan pisau, parang dan seperti alat-alat pertanian yang sudah mengikuti kemajuan zaman, mesin bajak, motor, mobil kemudian dari peralatan memasak juga sudah mengikuti kemajuan zaman. Kalau dulu masih memakai kayu bakar sekarang sudah ada yang menggunakan kompor minyak bahkan ada yang menggunakan kompor gas. Karena penduduk sudah hidup dalam zaman kecanggihan teknologi.

\footnotetext{
${ }^{25}$ Wawan, Penduduk Lokal Desa Padang Jering, Wawancara dengan Penulis, 12 Februari 2020, Desa Padang Jering, Wawancara.

${ }^{26}$ Ensiklopedi Suku Bangsa di Indonesia, hlm. 137-138. http://netralnews.com/news/rsn/read/94275/mengenal-suku-melayu-jambi))

${ }^{27}$ https://travel.detik.com/travel-news/d-4921040/mengenal-suku-jawa-sejarah-dankebudayaannya .
} 


\section{Sistem Mata Pencarian}

Mata pencarian merupakan segala usaha manusia untuk mendapatkan barang dan jasa yang dibutuhkan. Sistem ekonomi ini meliputi, berburu dan mengumpulkan makanan, bercocok tanam, peternakan, perikanan, dan perdagangan. Sistem mata pencaharian dalam unsur kebudayaan ini juga berkaitan dengan segala aktifitas yang dilakukan manusia untuk memenuhi kebutuhan ekonomi atau segala upaya yang dilakukan untuk memenuhi kehidupan sehari-hari.

Penduduk lokal dan pendatang di Desa Padang Jering memiliki sistem pencarian yang sama. Seperti sama-sama bertani, bercocok tanam dan yang membedakannya hanya dibidang pembudidayaan atau peternakan seperti budidaya ikan atau perikanan. Mata pencaharian penduduk lokal mereka terutama bercocok tanam di ladang yang mereka bagi menjadi empat bentuk, yaitu Parelak, Kabun Mudo, Umo Rendah dan Talang. Parelak adalah ladang dekat desa yang ditanami cabe, kacangkacangan dan sayur-sayuran. Kabun mudo adalah ladang yang ditanami tanaman muda, seperti pisang, kedelai dan kacang tanah. Umo rendah adalah ladang agak luas yang ditanami padi, dan di sekitarnya ditanami jagung, sorgum, ketimun dan lain-lain. Sedangkan umo Sedangkan talang adalah ladang yang terletak jauh dari desa, terutama ditanami padi dan tanaman sampingan lainnya, Selain bercocok tanam banyak juga yang bertani, nelayan, berdagang dan bekerja di sektor pemerintahan.

Sesuai hasil wawancara penulis dengan penduduk lokal Desa Padang Jering mengatakan bahwa,

"[S]istem mata pencarian penduduk local dengan penduduk pendatang tidak telalu berbeda karena masih menggunakan sistem mata pencarian yang sama, seperti berkebun, bertani dan penduduk pendatang pun juga melakukan hal yang sama dalam memenuhi kebutuhan mereka sehari-hari yang berbeda mungkin kalau penduduk pendatang ada yang berbudidaya ikan sedangkan kami disini tidak ada yang membudidayakan ikan hanya sebagian saja". ${ }^{28}$

Penduduk pendatang pun mengatakan hal yang sama dengan penduduk lokal mengenai sistem mata pencarian,

"[K]ami sebagai penduduk pendatang juga melakukan hal yang sama dengan penduduk local dalam hal untuk memenuhi kebutuhan sehari-hari yaitu bidang

${ }^{28}$ Rendi, Penduduk Lokal Desa Padang Jering, Wawancara dengan Penulis, 16 Februari 2020, Desa Padang Jering, Wawancara. 
ekonomi. Apalagi Desa Padang Jering adalah perbukitan maka mata pencariannya pun sama seperti bertani, berkebun, bersawah dan lain-lain". ${ }^{29}$

Berdasarkan hasil wawancara dan pengamatan penulis dilapangan bahwa dalam sistem mata pencarian bahwa penduduk lokal maupun penduduk pendatang sama-sama melakukan hal yang sama dalam sistem pencarian, seperti berkebun, bertani, berdagang dan lian-lain. Karena penduduk pendatang tinggal di Desa Padang Jering otomatis sistem pencarian yang digunakan penduduk pendatang sama dengan penduduk lokal. Beberapa hal juga yang menjadikan sistem pencariannya adalah lokasi tempat tinggal, keahlian, dan yang paling dominan adalah disebabkan oleh faktor georafis Desa Padang Jering yang daerah perbukitan.

\section{Sistem Religi}

Sistem religi mencakup kepercayaan, agama, hingga ritual-ritual adat yang diyakini oleh masyarakat. Dalam hal lain sistem religi juga diartikan sebagai sistem yang terpadu antara praktek agama dan keyakinan seseorang yang berkaitan dengan hal-hal sakral suci yang tidak dapat dijangkau oleh akal dan pikiran. Religi ini juga bisa berkaitan dengan nilai dan norma, pandagan hidup, upacara pernikahan, kematian, dan budaya masyarakat lainya.

Sistem religi suatu daerah pasti berbeda untuk daerah yang satu dengan daerah yang lain sesuai dengan kebudayaan, tradisi dan adat istiadat. Dari sistem keagamaan maupun kepercayaan penduduk lokal dan pendatang terdapat begitu perbedaan, bahwa secara umum semua masyarakat penduduk lokal Desa Padang Jering beragama Islam. Tetapi berbeda dengan penduduk lokal jika dibahas secara umum kepercayaan mereka masih ada yang beragama islam, Kristen, animise dan kepercayaan lain yang sesuai dengan kepercayaan didaerah dan yang mereka anut.

Sesuai dengan hasil wawancara penulis dengan kepala adat Desa Padang Jering mengatakan,

"[D]ari sistem religi dan kepercayaan bahwa semua penduduk lokal Desa Padang Jering menganut kepercayaan yang sama. Agama yang dianut semuanya

${ }^{29}$ Zamri, Penduduk Pendatang Desa Padang Jering, Wawancara dengan Penulis, 15 Februari 2020, Desa Padang Jering, Wawancara. 
beragama Islam. Tidak ada penduduk Desa Padang Jering yang tidak beragaama Islam, semua penduduk menganut agama yang sama". ${ }^{30}$

Kebudayaan yang berbeda penduduk lokal dan pendatang juga terjadi pada saat seorang ibu sedang mengandung maka biasanya penduduk pendatang akan mengadakan acara syukuran empat bulanan, tujuh bulanan. Tetapi berbeda dengan penduduk lokal tidak ada tradisi semacam itu pada saat seorang ibu sedang mengandung.

Sesuai dengan hasil wawancara penulis dengan penduduk pendatang mengatakan bahwa:

"[T]radisi pada daerah kami memang diadakan acara sykuran pada saat seorang ibu sedang mengandung, seperti acara empat bulanan, tujuh bulanan dan itu sudah merupakan tradisi dari nenek moyang kami yang secara turun temurun tetap dilestarikan sampai sekarang, tetapi berbeda dengan Desa Padang Jering bahwa tidak ada tradisi semacam itu di Desa ini". ${ }^{31}$

Selain selamatan, masyarakat Jawa juga mengenal upacara sesajen. Upacara ini berkaitan dengan kepercayaan terhadap makhluk halus. Sesajen diletakkan di tempattempat tertentu, seperti di bawah kolong jembatan, di bawah tiang rumah, dan di tempat-tempat yang dianggap keramat. Bahan sesajen berupa : ramuan tiga jenis bunga (kembang telon), kemenyan, uang recehan, dan kue apam. Bahan tersebut ditaruh di dalam besek kecil atau bungkusan daun pisang. Ada pula sesajen yang dibuat pada setiap malam Selasa Kliwon dan Jumat Kliwon yang wujudnya sangat sederhana karena hanya terdiri atas tiga macam bunga yang ditempatkan pada sebuah gelas yang berisi air, bersama sebuah pelita, dan ditempatkan pada sebuah meja. ${ }^{32}$

Dari hasil wawancara bahwa dapat peneliti simpulkan sistem religi penduduk lokal dengan penduduk pendatang begitu jauh berbeda, mulai keagamaan, kepercayaa, tradisi dan adat istiadatnya. Tetapi karena penduduk pendatang tinggal di daerah yang tidak menganut tradisi seperti yang dilakukan penduduk pendatang maka penduduk

\footnotetext{
${ }^{30}$ Muktar, Kepala Adat Desa Padang Jaring, Wawancara Dengan Penulis, 11 Februari 2020, Desa Padang Jering, Wawancara.

31 Indra, Penduduk Pendatang, Wawancara dengan Penulis, 11 Februari 2020, Desa Padang Jering, Wawancara

${ }^{32}$ https://jiwanejawi.wordpress.com/2013/12/30/sistim-religi-masyarakat-jawa-sistemkepercayaan/.
} 
pendatang tidak melaksanakan ritual mereka di Desa Padang Jering yang mana bertujuan untuk saling toleransi dan menghargai kebudayaan masing-masing.

6. Kesenian

Kesenian mencakup hasil kesenian yang diciptakan oleh masyrakat, misalnya seni rupa, musik, hingga tari-tarian. Tarian Tradisional : Tari Sekapur Sirih, Tari Selampit Delapan, Tari Rentak Besapih, Tari Kipas Keprak, Tari Tauh, Tari Selaras Pinang Masak, Tari Selendang Mak Inang, Tarian Magis Gadis. Seni rupa seperti batik Jambi (berfungsi sebagai pengisi motif pakaian adat Jambi) ${ }^{33}$

Suku Jawa merupakan salah satu suku yang terdapat di Indonesia. Suku ini menjadi suku yang memiliki populasi penduduk terbanyak di Indonesia. Hal inilah yang menjadikan kesenian dari Suku Jawa banyak dikenal oleh masyarakat Indonesia. Contoh kesenian yang menjadi ciri khas Suku Jawa adalah karawitan, wayang kulit, jathilan, sendratari, dan seni tari. Alat musik tradisonal seperti Langgam Jawa merupakan bentuk adaptasi musik keroncong ke dalam musik tradisional Jawa, khususnya gamelan.

Tetapi sesuai pengamatan peneliti bahwa kesenian tersebut baik penduduk lokal maupun penduduk pendatang banyak yang mulai punah karena terbawa oleh perubahan zaman. Baik dari kesenian tari, musik banyak yang sudah tidak melestarikannya lagi. Walaupun masih ada sebagian yang masih melestarikannya tetapi untuk zaman teknologi seperti sekarang kesenian tradisonal sudah mulai kurang diminati. Seharusnya kesenian ini harus tetap dilestarikan bahwa sebuah peninggalan bersejarah.

\section{Karakteristik Budaya Penduduk di Desa Padang Jering}

Bahasa adalah salah satu elemen terpenting dalam sebuah komunikasi. Bahasa suatu daerah tentu berbeda hal inilah yang membuat susah terjadinya komunikasi dan dalam berkomunikasi suatu daerah juga mempunyai ciri khas tersendiri, karena bahasa adalah elemen terpenting pada saat melakukan komunikasi. Tampa memahami bahasa komunikasi efektif tidak akan tercapai.

\footnotetext{
${ }^{33}$ Ensiklopedi Suku Bangsa di Indonesia, http://netralnews.com/news/rsn/read/94275/mengenal-suku-melayu-jambi))
} 
Sesuai dengan hasil wawancara penulis dengan kepala adat Desa Padang Jering mengatakan bahwa:

"[P]erbedaan sosial budaya sangat mempengaruhi praktek dalam komunikasi penduduk lokal dengan penduduk pendatang yang ada di Desa Padang Jering, karena begitu banyak perbedaan, yang paling berbeda adalah bahasa karena kami penduduk lokal Batang Asai memiliki bahasa yang khas daerah Batang Asai jadi untuk berkomunikasi dengan penduduk pendatang ada sebagian dari penduduk lokal yang bisa berbahasa Indonesia untuk tetap bisa berkomunikasi dan ada yang tidak bisa sama sekali dan membuat kami penduduk lokal semakin susah untuk berkomunikasi dengan penduduk lokal". ${ }^{34}$

Seperti penduduk pendatang yang berasal dari Jawa penduduk pendatang pada saat berkomunikasi memiliki cara tersendiri saat berkomunikasi dengan orang seperti memiliki aturan dalam berkomunikasi bahasa bahasa yang di gunakan berbeda seperti bekomunikasi dengan anak-anak, orang tua, teman sebaya, masing-masing memiliki gaya bicara tersendiri.

Sesuai hasil wawancra penulis dengan Yakin, penduduk pendatang menyatakan.

"[K]ami orang Jawa pada saat berkomunikasi dengan orang memiliki cara bericara dan bahasa yang berbeda pula untuk setiap orang, bahasa yang digunakan kepada orang tua berbeda dengan bahasa yang digunakan untuk anak-anak. Apalagi dengan teman sebaya, semuanya memiliki gaya bahasa tersendiri pada saat berkomunikasi. Supaya ada perbedaanya baik dengan orang tua, anak-anak maupun teman sebaya". ${ }^{35}$

Berbeda dengan penduduk lokal Desa Padang Jering yang tidak mempunyai cara tersendiri pada saat berkomunikasi dengan orang lain, gaya bahasa yang digunakan oleh penduduk lokal desa padang jering kebanyakan berkomunikasi dengan teman sebaya maupun dengan anak-anak dan bahkan dengan orang tua sekalipun ada sebagian masyarakat yang tidak mengunkan gaya bahasaya yang mana seharusnya di gunakan dalam berkomunikasi akan tetapi anak-anak muda dalam berkomunikasi dengan orang tua pun lebih banyak cenderung mengunakan gaya bahasa yang sama dengan seumuran mereka.

Tidak semua penduduk Desa Batang Asai menggunakan bahasa yang sopan pada saat berkomunikasi karena disana sudah terbiasa dengan logat bahasa yang keras dan

${ }^{34}$ Muktar, Kepala Adat Desa Padang Jaring, Wawancara Dengan Penulis, 11 Februari 2020, Desa Padang Jering, Wawancara.

35 Wawancara Yakin, Penduduk Pendatang Desa Padang Jering, Wawancara dengan Penulis, 11 Februari 2020, Desa Padang Jering. 
bernada kasar. Tentu bentuk komunikasi yang seperti ini akan mempengaruhi penduduk lokal ketika ingin berkomunikasi dengan penduduk lokal. Apalagi penduduk lokal nya adalah penduduk yang berasal dari suku jawa, yang mana suku terkenal dengan bahasa yang sopan, santun, dan bernada lemah lembut. Perbedaan dalam hal bahasa ini akan sangat mempengaruhi praktek komunikasi di Desa Padang Jering.

Berdasarkan pengamatan penulis dilapangan bahwa perbedaan sosial budaya yang sangat mempengaruhi praktek komunikasi penduduk lokal dengan penduduk pendatang adalah bahasa dan adat istiadat. Dan yang paling sangat mempengaruhi adalah bahasa, karena tampa bahasa yang benar maka komunikasi akan tidak akan berjalan dengan lancar. Penjelasan diatas maka dapat penulis simpulkan bahwa perbedaan sosial budaya sangat berpengaruh dalalam praktek komunikasi oleh penduduk lokal dan penduduk pendatang di Desa Padang Jering.

1. Pakaian dan Penampilan

Pakain dan penampilan yang digunakan penduduk lokal maupun penduduk pendatang jika untuk kehidupan sehari-hari tidak ada perbedaan baik dari penduduk lokal maupun penduduk pendatang. Tetapi jika dari pakain adat atau pakain tradisonal maka penduduk lokal dan pendatang akan jauh berbeda. Karena setiap daerah pasti memiliki pakaian adat atau pakain tradisonalnya sendiri. Seperti penduduk lokal memiliki pakaian tradisional seperti tengkuluk, sedangkan penduduk pendatang seperti blangkon.

Jika melangsungkan acara adat atau pernikahan maka yang digunakan adalah pakain tradisonal daerah masing. Seperti jika penduduk lokal melangsungkan acara pernikahan maka memakai pakaian adat daerah Desa Padang Jering. Tetapi jika penduduk pendatang dan penduduk lokal sama-sama melangsungkan pernikahan antarbudaya maka otomatis untuk menghargai budaya satu sama lain maka pemakian pakaian adat dilaksanakan secara bergantian. Karena masing-masing daerah memiliki kebudayaan masing-masing yang harus saling dihormati.

\section{E. Komunikasi Antarbudaya di Desa Padang Jering}

Masyarakat Indonesia merupakan masyarakat majemuk yang memiliki beragam etnis, budaya dan agama yang saling berinteraksi satu sama lain. interkasi tersebut 
dapat terwujud jika adanya sebuah proses komunikasi. karena manusia adalah mahluk sosial yang membutuhkan orang lain. Dalam suatu daerah pasti ada penduduk yang mendiami tempat tersebut baik penduduk lokal daerah tersebut maupun penduduk pendatang yang berasal dari luar daerah tersebut. Dengan adanya dua penduduk yang sama-sama tinggal pada satu daerah tentu akan memiliki perbedaan baik dari kebudayaan, ras, maupun cara berkomunikasi. Tanpa adanya komunikasi maka tidak akan terjadi proses interaksi antara kedua penduduk tersebut.

Sosial budaya atau kebudayaan adalah segala sesuatu atau nilai yang berlaku dalam sebuah masyarakat yang menjadi ciri khas dari masyarakat tersebut. Terciptanya sebuah kebudayaan atau sosial budaya dikarenakan adanya interkasi antar manusia. Daerah tertentu mempunyai sosial budaya yang beragam baik dari bahasa, religi, kesenian, dan unsur-unsur kebudayaan yang lainnya. Tentu daerah yang satu dengan daerah yang lain mempunyai perbedaan masing-masing dalam sosial budaya atau kebudayaan. Semakin besar derajat perbedaan antarbudaya maka akan susah pula untuk mendapatkan peluang komunikasi yang efektif, karena berkomunikasi dengan orang yang berbeda kebudayaan maka akan mengalami sebuah kesulitan dalam berkomunikasi.

Komunikasi yang terjadi pasti akan sedikit berbeda dengan komunikasi yang biasa digunakan oleh penduduk lokal tersebut karena lawan yang diajak berkomunikasi adalah penduduk pendatang yang memiliki kebudayaan tersendiri, tentu perlunya penyesuain bahasa oleh penduduk lokal dan penduduk pendatang.

Sesuai hasil wawancara dengan Muktar selaku kepala adat Desa Padang Jering mengenai komunikasi antarbudaya penduduk lokal Desa Padang Jering dan penduduk pendatang

[K]ami mengunakan bahasa Indonesia dalam berkomunikasi dengan penduduk pendatang agar terjalin komunikasi dengan penduduk lokal, selaku penduduk lokal disini kami mengunakan bahasa yang mudah di pahami dan dimengerti oleh pendatang kami memerlukan bertatap muka dalam berkomunikasi, dalam komunikasi bertatap muka kami mengunakan bahasa isyarat, agar memperlancar komunikasi yang ada di Desa Padang jering. ${ }^{36}$

${ }^{36}$ Muktar, Kepala Adat Desa Padang Jaring, Wawancara Dengan Penulis, 11 Februari 2020, Desa Padang Jering, Wawancara. 
Berdasarkan pengamatan penulis proses komunikasi antarbudaya oleh penduduk lokal dengan penduduk pendatang berlangsung sangat lama. Proses komunikasi ini memerlukan waktu untuk bisa saling memahami satu sama lain. terutama dalam memahami bahasa Desa Batang Asai tersebut, dan untuk memahami bahasa maupun kebudayaan di Batang Asai penduduk pendatang biasanya memerlukan waktu hampir satu tahun untuk bisa berinteraksi layaknya seperti penduduk lokal Desa Batang Asai.

Sesuai Hasil wawancara penulis dengan Indra selaku Penduduk Pendatang di Desa Padang Jering,

[S]aya sebagai penduduk pendatang untuk bersosialisasi dan berinteraksi dengan penduduk Desa Padang Jering membutuhkan waktu yang lumayan lama, bahkan saya hampir satu tahun untuk bisa memahami bahasa disini. Karena dalam waktu satu tahun tersebut saya gunakanan untuk memahami, belajar dan menafsirkan apa yang dibicarakan oleh penduduk disini. Karena kalau tidak saya pahami takutnya yang saya ucapkan itu salah. ${ }^{37}$

Berdasarkan penjelasan wawancara dapat penulis pahami bahwa dalam proses komunikasi yang dilakukan oleh penduduk pendatang adalah dengan cara memahami dan belajar bahasa Desa Padang Jering dan untuk memahami bahasa tersebut maka dibutuhkan waktu yang cukup lama. Penduduk lokal pun juga melakukan hal yang sama dengan penduduk pendatang, bahkan penduduk lokal ikut membantu penduduk pendatang untuk bisa berkomunikasi dengan penduduk lokal disana, seperti menafsirkan kepada penduduk pendatang apa yang sedang dibicarakan dengan menggunakan bahasa Indonesia.

Sesuai dengan hasil wawancara dengan Heri selaku penduduk lokal Desa Padang Jering,

"[P]roses komunikasi antarbudaya oleh penduduk lokal dan penduduk pendatang tentu membutuhkan waktu yang cukup lama untuk bisa saling memahami bahasa maupun kebudayaan masing-masing. Supaya komunikasi kami penduduk lokal tetap berjalan dengan penduduk lokal kadang kami saling membantu untuk bisa saling memahami bahasa masing-masing, seperti saling menafsirkan maksud dan tujuan pembicaraan". ${ }^{38}$

${ }^{37}$ Indra, Penduduk Pendatang, Wawancara dengan Penulis, 11 Februari 2020, Desa Padang Jering, Wawancara.

${ }^{38}$ Heri, Penduduk Lokal Desa Padang Jering, Wawancara dengan Penulis, 11 Februari 2020, Desa Padang Jering, Wawancara. 
Proses untuk memahami bahasa dan kebudayaan memang membutuhkan waktu yang lumayan lama. Sehingga dengan waktu tersebut maka akan bisa saling memahami dan bisa menerima maksud dan tujuan pembicaran baik dari penduduk lokal kepada pendatang maupun dari penduduk pendatang kepada penduduk lokal. Sampai kegiatan komunikasi ini bisa meghasilkan hubungan saling timbal balik.

Dalam sebuah proses komunikasi antarbudaya diperlukan adanya kesesuaikan pada unsur-unsur kebudayaan yang saling berbeda sehingga terdapat keserasian fungsi yang muncul dalam kehidupan bermasyarakat. Dalam komunikasi antarbudaya yang lebih ditekankan dalam hal toleransi, empati, dan positive thingking. Jalinan hubungan antar manusia dengan latar belakang budaya atau etnis yang berbeda dapat di warnai dengan munculnya konflik. Oleh karena itu diperlukanlah tiga aspek tersebut.

Sesui hasil wawancara dengan Wawan selaku penduduk lokal Desa Padang Jering

"[K]ami selaku penduduk lokal begitu sangat toleransi kepada penduduk pedatang karena jika tidak ada saling toleransi maka komunikasi kami tidak akan lancar dan cara kami bertoleransi dengan mereka seperti saling memahami bahasa dan kebudayaan masing-masing. Begitupun sebaliknya penduduk pendatang juga saling memahami kebudayaan dan cara kami berkomunikasi disini". ${ }^{39}$

Dalam komunikasi antarbudaya sengat diperlukan sifrat toleransi jika tidak mengunakan sifat bertoleransi dalam berkomunikasi maka komunikasi yang dijalin tidak akan berjalan dengan lancar.

Sesuai hasil wawancara penulis dengan Yakin selaku penduduk pendatang di Desa Padang Jering

"[K]ami sebagai penduduk pendatang juga mengunakan sikap toleransi terhadap penduduk lokal kenapa kami juga mengunakan sikap toleransi karnakami inging menujutkan komunikasi antar budaya antara penduduk lokal dan pendatang dan bahkan kamisebagai pendatang juga tidak ingin kehadiran kami di desa padang jering ini membuat penduduk lokal desa padang jering merasa terganggu dengan ke hadiran kami". ${ }^{40}$

Sesuai hasil wawancara penulias dengan Nika lova selaku penduduk pendatang,

\footnotetext{
${ }^{39}$ Wawan, Penduduk Lokal Desa Padang Jering, Wawancara dengan Penulis, 12 Februari 2020, Desa Padang Jering, Wawancara.

${ }^{40}$ Yakin, Penduduk pendatang di jawa, Wawancara dengan Penulis, 17 Februari 2020, Desa Padang Jering, Wawancara
} 
[S]aya sebagai penduduk pendatang untuk bersosialisasi dan berinteraksi dengan penduduk Desa Padang Jering membutuhkan waktu yang cukup lama, bahkan setengah tahun untuk bisa berkomunikasi dengan penduduk lokal. Untuk memahami bahasa membutuhkan waktu yang sangat lama untuk bisa mengerti dan tau cara berbahasa disini". ${ }^{41}$

Berdasarkan penjelasan wawancara dapat penulis pahami bahwa dalam proses komunikasi yang dilakukan oleh penduduk pendatang adalah dengan cara memahami dan belajar bahasa Desa Padang Jering dan untuk memahami bahasa tersebut maka dibutuhkan waktu yang cukup lama. Berdasarkan hasil wawancara tersebut dapat penulis pahami dalam komunikasi antarbudaya diperlukan penyesuaian diantara unsurunsur kebudayaan yang saling berbeda sehingga mencapai keserasian fungsi dalam kehidupan bermasyarakat. Sebagai masyarakat pendatang tentu saja juga perlu berinteraksi dan berkomunikasi dengan masyarakat serta bisa menyesuaikan diri dengan lingkungan barunya untuk dapat tetap hidup dengan baik. Karena budaya satu etnik dengan etnik lain mempunyai perbedaan, bahasa, agama, budaya, kebiasaan, dan lainnya. Apalagi dalam bahasa tentunya sangat berbeda masing-masing etnik.

\section{F. Hambatan Semantik Komunikasi Antarbudaya}

Berkomunikasi tentu akan ada hambatan yang akan terjadi, apalagi berkomunikasi dengan orang-orang yang memiliki kebudayaan yang berbeda. Baik dari perbedaan bahasa, ras, suku maupun kebudayaan. Oleh karena itu tentunya penduduk lokal Desa Padang Jering mempunyai hambatan dalam berkomunikasi dengan penduduk pendatang. Hambatan semantik ialah hambatan yang disebabkan oleh kesalahan dalam penafsiran, kesalahan dalam memberikan pengertian terhadap bahasa (kata-kata, kalimat, kode) yang dipergunakan dalam proses komunikasi.

Bahasa merupakan suatu bunyi yang di hasilkan dari ucapan manusia yang dilakukan tanpa sadar, sehingga membentuk pola bahasa sesuai dengan dialek tiap karakter manusia, bahasa memiliki pengertian sebagai sistem simbol vokal arbitrer yang memiliki kemungkinan dari semua orang dalam suatu kebudayaan tertentu. Atau orang

\footnotetext{
${ }^{41}$ Nika Novela, Penduduk pendatang di jawa, Wawancara dengan Penulis, 17 Februari 2020, Desa Padang Jering, Wawancara
} 
lain yang ingin mempelajari sisitem kebudayaan. Untuk melakukan komunikasi yang memudahkan sisitem interaksi antara sesama manusia.

Bahasa juga alat yang digunakan untuk dapat berkomunikasi sehari-hari, baik bahasa lisan ataupun bahasa tulisan. sebagai negara Indonesia tentunya bahasa persatuan adalah bahasa Indonesia, tetapi karena Idonesia memiliki banyak keberagaman kebudayaan dan salah satunya adalah bahasa. Begitu pula dengan bahasa yang di gunakan oleh penduduk suatu daerah. Tentu daerah tersebut mempunyai ciri khas bahasa daerah tersendiri. Tetapi terkadang bahasa juga merupakan salah satu hambatan dalam berkomunikasi dengan orang lain. apalagi dengan orang-orang yang berbeda daerah maupun berbeda kebudayaan. Sehingga komunikasi akan tergaggu dan interaksi sosial tidak berjalan dengan baik.

Meskipun bahasa merupakan alat komunikasi yang paling efektif, tetapi bahasa dapat juga menjadi hambatan dalam proses komunikasi apabila bahasa yang dipergunakan dalam berkomunikasi tidak dimengerti oleh orang lain sebagai penerima pesan komunikasi.

Sesuai hasil wawancara penulis dengan Sopyan selaku Kepala Desa Padang Jering mengena bahasa merupakan salah satu hambatan dalam komunikasi antarbudaya terutama dengan penduduk pendatang.

"[S]aya sebagai kepala desa juga mengakui bahwa ketika berkomunikasi dengan penduduk pendatang susah dalam berkomunikasi karena bahasa daerah Batang Asai berbeda pula dengan bahasa yang digunakan penduduk pendatang, dan kami di Batang Asai tidak faham bahasa mereka dan apalagi mereka juga akan susah memahami bahasa di Daerah kami ini. Kalau kita bisa berbahasa Indonesia ya mudah dalam berkomunikasi dengan mereka tapi sebagian dari penduduk Padang Jering ada yang kurang bisa bahasa Indonesia, nah inilah yang akan membuat penduduk lokal dan pendatang makin susah dalam berkomunikasi". ${ }^{42}$

Fitria selaku penduduk Pendatang juga mengatakan bahwa bahasa juga menjadi hambatan ketika berkomunikasi dengan penduduk lokal di Desa Padang Jering.

"[S]aya awal ke Desa Padang Jering Susah sekali mau berkomunikasi dengan orang disini, karena saya tidak faham bahasanya, jangan ingin berkomunikasi dengan penduduk disini bahkan arti dari bahasanya saja saya tidak tahu. Butuh watu satu tahun untuk saya bisa memahami bahasa di Padang Jering ini dan kalau saya menggunakan bahasa Indonesia setiap ingin berkomunikasi tetapi tidak semua penduduk lokal Desa Padang Jering yang mengerti bahasa Indonesia, jadi dalam

${ }^{42}$ Sopyan, Kepala Desa Padang Jering, Wawancara dengan Penulis, 13 Februari 2020, Desa Padang Jering, Wawancara. 
berkomunikasi saya sangat susah dan butuh pemahaman untuk bisa berkomunikasi dengan mereka. ${ }^{43}$

Seperti contoh penggunaan bahasa "kamu" dan penggunaan bahasa kamu jika dalam bahasa daerah Desa Padang Jering disebut "kau". Penggunaan bahasa "kamu/kau" kepada orang yang lebih tua pada saat berkomunikasi di Desa Padang Jering tidak terlalu diperhatikan bahkan sudah biasa terjadi tetapi berbeda dengan penduduk pendatang penggunaan bahasa "kamu" kepada orang yang lebih tua diaggap kasar karena penduduk pendatang ada aturan tertentu ketika akan berkomunikasi sesuai dengan lawan bicaranya.

Dapat peneliti pahami bahwa bahasa sangat berperan penting dalam sebuah proses komunikasi, karena tampa memahami bahasa satu sama lain maka akan sangat sulit terjadi interaksi sosial dan proses komunikasi pun tidak akan berjalan dengan baaik. Bahasa yang digunakan oleh orang yang berbeda kebudayaan tentu berbeda pula, baik penduduk lokal memiliki bahasa daerah yang khas dan begitu juga dengan penduduk pedatang di Desa Padang Jering.

\section{a. Logat berbicara}

Bahasa dikenal juga dengan nada berbicara, logat dan kode berbicara. Logat bahasa yang digunakan bisa juga sebagai penghambat dalam berkomunikasi, logat bahasa yang digunakan di Desa Padang Jering memiliki logat yang keras dan bernada kasar.

Wawancara penulis dengan Suan selaku penduduk pendatang yang berasal dari Daerah Jawa mengenai logat bahasa Daerah Batang Asai berbeda dengan logat bahasa Jawa.

"[L]ogat orang Desa Padang Jering ini keras dan kata-kata yang diucapkan terdengar kasar, kemudian nada-nada bicaranya keras dan terdengar kasar. Kadang-kadang saya berfikir orang yang saya ajak berkomunikasi itu marah tapi ternyata emang modelnya seperti itu, apalagi karena saya berasal dari jawa otomatis mendengar logat tersebut adalah hal yang aneh buat saya". ${ }^{44}$

Ditambahkan oleh Zamri penduduk Pendatang mengatakan:

${ }^{43}$ Fitria, Penduduk Pendatang Desa Padang Jering, Wawancara dengan Penulis, 14 Februari 2020, Desa Padang Jering, Wawancara.

${ }^{44}$ Suan, Penduduk Pendatang Desa Padang Jering, Wawancara dengan Penulis, 15 Februari 2020, Desa Padang Jering, Wawancara. 
"[I]ya bahasa yang di gunakan oleh peduduk lokal Desa Padang Jering ini bernada keras dan terdengar kasar, jauh berbeda dengan bahasa yang di gunakan oleh penduduk lain bahkan, pertama kali saya berada di Desa Padang Jering ini saya berpikir setiap orang berkomunikasi dengan saya itu semuanya marah tetapi setelah saya belajar bahasa yang digunakan oleh penduduk lokal disini baru lah saya paham pesan yang di sampaikan oleh penduduk lokal kepada saya yang saya angap marah ternyata itu semua adalah untuk mengajarkan kebaikan untuk bermasyarakat di Desa Padang Jering". ${ }^{45}$

Kemudian Rendi selaku penduduk lokal Padang Jering membenarkan pernyataan dari Zamri mengenai logat bahasa daerah Batang Asai yang kasar dan bernada tinggi.

"[M]emang betul yang mereka katakan bahwa logat dan nada bahasa daerah saya ini terdengar kasar dan keras bahkan banyak penduduk yang baru datang ke Daerah Batang Asai jarang berkomunikasi dengan kami dan ketika ditanya kenapa mereka jarang berkomunikasi mereka mengatakan mereka takut untuk berkomunikasi karena merasa kami marah kepada mereka". ${ }^{46}$

Dapat dipahami bahwa kesalahan penafisiran mengenai logat bahasa penduduk lokal Desa Padang Jering terhadap proses komunikasi penduduk pendatang dengan penduduk lokal juga mengahmbat terjadinya komunikasi karena logat bahasa bisa berubah sesuai dengan penafsiran seseorang walaupun maksud dan tujuan sebenarnya berbeda dengan apa yang ditafsirkan oleh orang lain.

Melalui pengamatan peneliti selama di Desa Padang Jering mengenai komunikasi antarbudaya penduduk lokal dan penduduk pendatang bahwa kesalahan penafsiran bukan hanya terjadi dalam bentuk logat bahasa tetapi juga terjadi kesalahan penafisran dalam kode bicara. Karena penduduk pendatang terkadang salah menafsirkan kode bicara yang digunakan oleh penduduk lokal Desa Padang Jering. Kesalahan penafsiran ini yang membuat penduduk lokal kesulitan untuk berkomunikasi dengan penduduk pendatang. Bahkan kode bicara yang dianggap baik oleh penduduk lokal belum tentu sama penafsiran oleh penduduk pendatang. Begitu juga sebaliknya kode bicara yang digunakan oleh penduduk pendatang belum tentu bisa diterima sepenuhnya oleh penduduk lokal.

Sesuai wawancara peneliti dengan Yudi penduduk lokal Desa Padang Jering mengenai seringg terjadi kesalahan dalam penafsiran kode bicara.

${ }^{45}$ Zamri, Penduduk Pendatang Desa Padang Jering, Wawancara dengan Penulis, 15 Februari 2020, Desa Padang Jering, Wawancara.

${ }^{46}$ Rendi, Penduduk Lokal Desa Padang Jering, Wawancara dengan Penulis, 16 Februari 2020, Desa Padang Jering, Wawancara. 
"[P]enduduk pendatang terkadang salah penafsiran dari kode bicara yang kami gunakan ketika berkomunikasi dengan mereka penduduk pendatang, seperti kami mengatakan "kamu" jika diartikan maka kamu itu berarti sekelompok orang tetapi penduduk pendatang dari daerah kerinci mengartikan kamu itu adalah menunjukkan satu orang dan penggunakan kata kamu itu dianggap kasar oleh penduduk lokal yang berasal dari Kerinci tersebut". ${ }^{47}$

Usman sebagai penduduk pendatang membenarkan pernyataan Yudi bahwa terjadi kesalahan penafisiran dari kode bicara yang digunkan ketika berkomunikasi.

"[S]aya penduduk pendatang memang pernah salah mengartikan kode bicara penduduk Batang Asai karena misalnya penggunaan bahasa kamu itu kode bicara yang mengartikan untuk satu orang tetapi di Desa Padang Jering digunakan untuk menunjukkan sekelompok orang dan kami pengunaan kata "kamu" itu terdengar kasar tetapi disini meraka biasa saja menggunkan kata-kata "kamu" tersebut". ${ }^{48}$

Dapat di simpulkan perbedaan kode bahasa yang di gunakan oleh penduduk lokal dan pedatang di Desa Padang Jering bahwa kode Bahasa "kamu" sangat jauh perbedaan nya dengan kode bahasa yang di gunakan oleh penduduk lokal. Jadi banyak penduduk pedatang beranggapan atau salah pemahaman, logat dan bahasa yang di gunakan oleh penduduk lokal di Desa Padang Jering memang terdengar keras dan kasar bagi pendatang yang ada di Desa Padang Jering yang pertama kali masuk ke Desa Padang Jering ini $90 \%$ penduduk merasa tidak nyaman setelah belajar dan memahami bahasa tersebut penduduk pendatang mulai merasa nyaman dan terbiasa mendengar logat maupun kode bahasa.

\section{G. Upaya Mengatasi Hambatan Komunikasi Lokal-Pendatang di Desa Padang Jering}

Upaya yang dilakukan penduduk lokal dan pendatang untuk menghindari hambatan semantik, yang mana hambatan semantik adalah hambatan yang disebabkan oleh perbedaan bahasa. Maka yang dilakukan untuk menghindari hambatan semantik ini adalah dengan cara menggunakan bahasa Indonesia. Bahasa Indonesia merupakan bahasa persatuan, dalam berkomunikasi tentu juga diperlukan bahasa Indonesia karena

\footnotetext{
${ }^{47}$ Yudi, Penduduk Lokal Desa Padang Jering, Wawancara dengan Penulis, 16 Februari 2020, Desa Padang Jering, Wawancara.

${ }^{48}$ Usman, Penduduk Pendatang Desa Padang, Wawancara dengan Penulis, 16 Februari 2020, Desa Padang Jering, Wawancara.
} 
tidak semua orang akan bisa mengerti dan memahami bahasa daerah atau bahasa suatu daerah, bahasa Indonesia bisa digunakan untuk proses komunikasi agar komunikasi bisa tetap berjalan. Begitu juga yang terjadi di Desa Padang Jering bahwa untuk komunikasi tetap bisa berjalan dengan lancar maka penduduk local Desa Padang Jering menggunakan bahasa Indonesia supaya tetap bisa berkomunikasi dengan penduduk pendatang yang belum memahami bahasa Desa Padang Jering.

Sesuai dengan hasil wawancara dengan Suni selaku penduduk local Desa Padang Jering.

"[S]elain berkomunikasi dengan menggunakan bahasa isyarat maka kami juga menggunakan bahasa Indonesia untuk menyampaikan maksuda dan tujuan kami kepada penduduk pendatang karena otomatis jika menggunakan bahasa Indonesia maka penduduk pendatang akan memahami dan mengerti tujuan atau pun pesan yang ingin disampakain. Karena komunikasi menggunakan bahasa daerah Desa Padang Jering maka mereka tidak akan memahami maka untuk menghindarinya maka digunakanlah bahasa Indonesia". ${ }^{49}$

Berdasarkan pengamatan penulis bahwa sebagian penduduk lokal Desa Padang Jering yang bisa menggunakan bahasa Indonesia maka mereka akan menggunakan bahasa Indonesia pada saat berkomunikasi dengan penduduk pendatang, dan dapat penulis simpulkan bahwa bahasa Indonesia bisa digunakan untuk menghindari hambatan komunikasi oleh penduduk lokal terhadap penduduk pendatang. Tetapi tidak semua penduduk lokal Desa Padang Jering yang bisa menggunakan bahasa Indonesia untuk berkomunikasi dengan penduduk pendatang, karena masih ada sebagian dari penduduk lokal yang tidak bisa berbahasa Indonesia. Tentu hal tersebut juga akan menghambat proses komunikasi maka untuk menghindari hambatan tersebut dan supaya komunikasi tetap bisa berjalan dengan lancer, baik komunikasi verbal maupun komunikasi non verbal maka penduduk lokal dan pendatang melakukan upaya sebagai berikut:

\section{Mengunakan Bahasa Isyarat}

Bahasa isyarat bahasa yang mengutamakan komunikasi manual, bahasa tubuh, dan gerak bibir, bukannya suara, untuk berkomunikasi, seperti orang tuli kelompok utama yang menggunakan bahasa ini, biasanya dengan mengkombinasikan bentuk

${ }^{49}$ Suni, Penduduk Lokal Desa Padang Jering, Wawancara dengan Penulis, 17 Februari 2020, Desa Padang Jering, Wawancara. 
tangan,oreantasi dan gerak tangan, lengan, dan tubuh serta ekpresi wajah untuk mengunggkapkan pikiran mereka.

Komunikasi yang digunakan bukan hanya komunikasi secara verbal tetapi bisa juga menggunkan komunikasi nonverbal yang mana tujuannya sama untuk saling berkomunikasi walaupun cara ataupun media yang digunakan berbeda. Komunikasi akan tetap berjalan walaupun hanya menggunakan bahasa isyarat, seperti bahasa tubuh. Dalam bahasa isyarat memerlukan bertatap muka antara komunikator dengan komunikan di dalam berkomunikasi antara satu orang atau lebih tentu saja ada bahasa isyarat yang di gunakan seperti mimik wajah, gerak tangan, dan sikap.

Sesuai dengan hasil wawancara dengan Fauzan selaku penduduk lokal Desa Padang Jering

"[S]ebagai penduduk local terkadang pada saat melihat penduduk pendatang yang baru di Desa kami ini tentu kami sudah memahami bahwa mereka belum mengerti bahasa di Desa Padang Jering tentu hal ini akan membuat mereka susah untuk berkomunikasi dengan kami disini untuk menghindari itu semua dan supaya tidak terjadi konflik maupun kesalah fahaman maka kami terkadang menegur mereka terlebih dahulu seperti senyum". ${ }^{50}$

Senada juga dengan yang dikatakan Usman selaku penduduk pendatang mengatakan hal yang sama dengan Fauzan,

"[S]aya selaku penduduk pendatang di Desa Padang Jering hal pertama yang bisa saya lakukan untuk tetap bisa berkomunikasi dengan penduduk di Desa adalah dengan cara menggunakan komunikasi isyarat, yaitu senyum kenapa hal itu saya lakukan supaya komunikasi saya tetap bisa berjalan dengan lancar dan tidak mendatangkan konflik dan prasangka buruk oleh orang-orang kepada saya" ${ }^{51}$

Berdasarkan hasil pengamatan penulis dilapangan bahwa penduduk pendatang maupun penduduk lokal ketika berkomunikasi menggunakan bahasa isyarat untuk tetap bisa berkomunikasi, dan dapat disimpulkan bahwa bahasa isyarat begitu sangat penting dalam proses komunikasi apalagi komunikasi dengan orang yang berbeda kebudayaan terutama dalam hal berkomunikasi karena jika tidak menggunakan bahasa isyarat maka akan mendatangkan konflik dan prasangka yang tidak baik.

${ }^{50}$ Fauzan, Penduduk Lokal Desa Padang Jering, Wawancara dengan Penulis, 16 Februari 2020, Desa Padang Jering, Wawancara.

${ }^{51}$ Usman, Penduduk Pendatang Desa Padang Jering, Wawancara dengan Penulis, 16 Februari 2020, Desa Padang Jering, Wawancara. 


\section{Melalui bantuan orang lain}

Dalam proses komunikasi atau berinteraksi. Dan orang ketiga ini lah yang akan bertugas untuk menyampaikan maksud dan tujuan baik komunikator maupun komunikan,orang ketiga disini boleh berasal dari daerah tersebut maupun orang luar yang sudah memahami kebudayaan daerah setempat, sesuai dengan hasil wawancara penulis dengan Indra

"[I]ndra mengatakan dia mengunakan orang ketiga iya itu istrinya, untuk belajar bahasa di desa padang jering dalam peroses belajar atau memahami dan terus berusaha memahami bahasa dan pengucapan kata kata atau menyesuaikan kalimat yang ingin di menyampaikan maka memakan waktu satu tahun untuk bisa berkomunikasi mengunakan bahasa asli desa padang jering". ${ }^{52}$

Upaya yang di lakukan oleh Indra agar tidak terjadinya hambatan komunikasi maka digunakanlah orang ketiga untuk melancarkan pesan yang ingin disampaikan dalam hasil wawancara indra orang ketiga disini istrinya sendiri di didalam proses pemahaman bahasa terdebut maka memakan waktu yang cukup lama.

Sesuai wawancara penulis dengan dengan Peduduk lokal Desa Padang Jering Wahyudi

Penduduk Lokal Desa Padang Jering:

"[M]emang benar bahawa penduduk pendatang Pertama kali masuk ke Desa Padang Jering ini kami selaku penduduk lokal kami menghormati pendatang yang sudah berada di Desa kami, kami selaku pdenduduk lokal kami negajarkan banayak hal dalam beradap tasi denga penduduk lokal supaya pendatang yang ada di Desa kami agar tidak terjadi hambatan komunikasi maka kami selaku penduduk lokal kami sebagai pelantara atau media orang ketiga dalam komunikasi antar budaya". ${ }^{53}$

Ada sebagian penduduk lokal membantu penduduk pendatang untuk belajar memahami bahasa dan kebudayan yang ada di Desa tersebut guna agar tdiak terjadinya hambatan bahkan penduduk lokal pun sanggup menjak pendatang untuk belajar bersosialisi denga penduduk lokal.

Dalam berkomunikasi antarbudaya tentu ada hambatan dalam berkomunikasi, maka diperlukanlah upaya agar menghindari hambatan komunikasi adapun upaya-upaya

\footnotetext{
${ }^{52}$ Indra, Penduduk Pendatang Desa Padang, Wawancara dengan Penulis, 17 Februari 2020, Desa Padang Jering, Wawancara.

${ }^{53}$ Wahyudi , Penduduk Lokal Desa Padang Jering, Wawancara dengan Penulis, 17 Februari 2020, Desa Padang Jering, Wawancara.
} 
yang di lakukannya, seperti mengunakan media atau perantara orang yang benar-benar memahami dan menguasai dalam berkomunikasi anatarbudaya guna agar tidak terjadi hambatan dalam berkomunkasi.

Wawancara penulis dengan Sopiyan Selaku penduduk lokal di Desa Padang Jering,

"[U]paya yang dilakukan penduduk lokal mengunakan bahasa asli Desa Padang Jering jika pendatang idak mengerti bahasa asli makan di mengunakan mendia atau orang ketiga dalam berkomunikasi dengan pendatang seperti orang yang memahami bahasa yang di gunakan pendatang agar terciptanya komunikasi antarbudaya"..$^{54}$

Dengan adanya upaya yang di lakukan oleh penduduk lokal Desa Padang Jering untuk berkomunikasi antar budaya maka mengunakan media seperti menunjukan sesuatu yang sulit di jelaskan dalam dua bahasa contoh menunjukan makanan khas atau ada acar pernikahan itu mengunakan media

Hasil Wawancara penulis dengan pendatang Sri wahyuni mengatakan

"[P]enyesuaian kebudayaan yang berbeda dan berusaha memahami kebudayaan lingkungan sesuai dengan pepatah adat istiadat di mana tamilang di cacak di situ tanaman tumbuh di mana bumi di pijak di situ langit di junjung bahkan dalam bahasa mengunakan bahasa indonesia di mana bumi di injak di disitu langit di junjung adalah langakah utama yang di lakukan oleh penduduk pendatang, media yang di gunakan adalah mengunakan pelantara orang yang betul betul mengerti dua bahasa yang di gunakana oleh pendatang dan penduduk lokal, dan juaga mengunakan bahasa insyarat di perlukanlah bertatap muka". ${ }^{55}$

Dari hasil wawancara penulis dapat di simpulkan bahwa Penduduk Pedatang berusaha memahami dan mempelajari, dalam peroses belajar mahami bahasa dan kebudayaan yang ada di desa padang jering maka di perlukanlah langkah-langkah awal seperti belajar memahami bahasa dan karakter yang ada di sekitar lingkungan langkah kedua mengunakan media orang ketiga dalam proses berkomunkasi.

Berbagai upaya yang dilakukan oleh penduduk lokal kepada penduduk pendatang agar terciptanya interaksi sosial antara penduduk jika sudah terjalin maka terciptalah komunikasi antara penduduk lokal dan pendatang dan pendatang pun bisa belajar memahami kebudayaan yang ada di sekitar.

${ }^{54}$ Sopyan, Penduduk Lokal Desa Padang Jering, Wawancara dengan Penulis, 17 Februari 2020, Desa Padang Jering, Wawancara

${ }^{55}$ Sri Wahyuni, Penduduk pendatang di jawa, Wawancara dengan Penulis, 17 Februari 2020, Desa Padang Jering, Wawancara 
Wawancara penulis dengan usron sebagai penduduk lokal Desa Padang Jering, "[K]ebanyakan penduduk pendatang lebih banyak mengunakan media pelantara atau menggunakan orang ketiga dalam berkomunikasi agar terciptanya komunikasi antarbudaya, karena manusia mahluk sosial maka kami sebgai penduduk lokal wajib megayomi dan mengajarkan penduduk pendatang berkomunikasi antar penduduk dan penduduk lokal juga bersedia untuk menjadi orang ketiga dalam komunikasi antar budaya". ${ }^{56}$

Dapat simpulkan dari hasil wawancara penulis bahwa kebanyakan mengunakan media atau perantara orang ketiga dalam berkomunikasi, penduduk lokal pun juga bersedia menjadi media atau perantara dalam berkomunikasi dan penduduk penduduk lokal juga mengajarkan bagaimana komunikasi yang ada di Desa tersebut.

\section{H. Penutup}

Perbedaan sosial budaya penduduk lokal dan penduduk pendatang yang ada di Desa Padang Jering memerlukan komunikasi antara budaya sebagai jembatan. Hambatan komunikasi yang ada adalah Bahasa. Upaya dalam menghindari hambatan komunikasi antarbudaya penduduk lokal dan pendatang di Desa Padang Jering dengan menggunakan bahasa Indonesia ketika ingin berkomunikasi. Kemudian juga menggunakan upaya yang pertama, menggunakan bahasa isyarat. Menggunakan bahasa isyarat untuk tetap bisa berkomunikasi seperti senyum. Kedua dengan menggunakan bantuan orang lain, seperti penduduk lokal menjadi perantara penduduk pendatang untuk berkomunikasi dengan penduduk lokal seperti mengartikan dan mengjarkan bahasa Desa Padang Jering. Penelitian ini menyarankan untuk saling membangun pemahaman dalam perbedaan, menciptakan sikap toleransi agar dapat berkomunikasi dengan lancar dan dapat menghindari hambatan komunikasi antarbudaya.

\section{Daftar Pustaka}

Ahmad, Sihabudin. Komunikasi AntarBudaya Satu Persfektif Multidimensi. Jakarta: PT Bumi Aksara, 2011.

${ }^{56}$ Usron, Penduduk Lokal Desa Padang Jering, Wawancara dengan Penulis, 18 Februari 2020, Desa Padang Jering, Wawancara 
Al-Qur'an Tajwid dan Terjemahan, Jakarta Timur: Magrifah, 2006.

Bungin, M.Burhan. Sosiologi Komunikasi, Teori, Paradigma dan Di skursus Tekonologi Komunikasi Di Masyarakat Jakarta: Kencana Pranada Media Grup, 2006.

Chesoh, Muhammad Lapse. "Komunikasi Antarbudaya Studi Model Koumunikasi Mahasiswa Pattani UIN Sunan Kalijaga Terhadap Masyarkat Gowok Yogyakarta". Skripsi. Yogyakarta: UIN Sunan Kalijaga,2016. (diunduh senin 25 November 2019, pukul 15:00).

Melati Budi Srikandi, "Komunikasi Antarbudaya penduduk pendatang dan penduduk" asli, https://jurnaltech.wordpress.com, ( diunduh minggu 01 Desember 2019 pukul 16:32).

Moleong, Lexi J. Metode Penelitian Kualitatif, Bandung: Remaja Rosdakarya, 2000.

Muhammad Mufid, Komunikasi dan Regulasi Penyiaran, Jakarta: Kencana Prenada Media Group,2005.

Mukhtar.Bimbingan Skripsi, Tesis dan Artikel Ilmiah .Jambi: Sultan Thaha Press, 2007.

Mulyana, Dedy. Komunikasi AntarBudaya Panduan Berkomunikasi Dengan Orang-orang Berbeda Budaya, Bandung: PT.Remaja Rosdakarya, 2014.

Prindono, Tito Edy. Komunikasi Keberagaman. Bandung: Remaja Rosdakarya, 2016.

Rivai, Veithzal dan Deddy Mulyadi. Kepemimpinan Dan Perilaku Organisasi. Jakarta: Raja Grafindo Persada,2012.

Shoelhi, Muhammad. Komunikasi Lintas Budaya Dalam Dinamika Komunikasi Internasional, Bandung: Simbiosa Rekatama Media, 2015.

Sugiono, Metode Penelitian Kuantitatif, Kualitatif dan R\&D, (Bandung: Alfabeta,2009.

Sugiyono. METODE PENELITIAN KUANTITATIF, KUALITATIF, DAN R\&D, Bandung; Alfabeta, 2016. 
Suparlan, Edi. “Dinamika Komunikasi antar budaya dan Agama di desa Tawakua Kabupaten luwu timur (studi kasus etnik bali dan jawa)",Skripsi Makassar: Universitas Alauddin Makassar,2013. (diunduh senin 25 November 2019, pukul 14:30).

Tim Penyusun, Panduan Penulisan Karya IImiah Mahasiswa Fakultas Ushuluddin IAIN Sultan Thaha Saifuddin Jambi, Jambi : Fak.Ushuluddin IAIN STS jambi, 2016.

Vebrynda ,Rhafidila."Persepsi antarbudaya”, Jurnal Komunikator. (diunduh minggu 01 Desember 2019.

Wafda, Ila Khaifa. "peran identitas suku jawadalam komunikasi antar budaya (studi deskriptif kualitatif alumni pondok modern darussalam gontor putri yang ada di demak)", Skripsi. Surakarta: Universitas Muhamadiyah Surakarta, 2014. (diunduh senin 25 November 2019, pukul 11:00).

Zulyani, Hidayah (April 2015). Ensiklopedi Suku Bangsa di Indonesia (edisi ke-2). Jakarta: Yayasan Pustaka Obor Indonesia.

Zuriah, Nurul. Metode Penelitian Sosial dan Pendidikan Teori-Aplikasi. Jakarta: Bumi Aksara, 2007, Cetakan I. 